\title{
A Review of Ecosystem Service Studies: Concept, Approach and Future Work in Korea
}

\author{
Min Gon Chung \& Hojeong Kang* \\ School of Civil and Environmental Engineering, Yonsei University
}

\begin{abstract}
In South Korea, the conflict between development and conservation policy still exist among government ministries, and conventional development plan often has priority over conservation policy. Establishment of sustainable development and comprehensive management policy employing the results of ecosystem service studies are highly warranted, but researchers in South Korea are still limited and often misuse the concept of ecosystem services. Thus, we aimed to introduce the concept of Ecosystem Service (ES) and related terminologies such as Social-Ecological Systems (SESs), ecosystem function, trade-off, and human well-being in this paper. Additionally, this article reviewed and arranged key approaches in ES studies as follows: 1) field works, 2) mapping ecosystem services, 3) valuing ES, 4) quantifying trade-offs between ES and 5) understanding SESs. Based on those results, we suggest that field works for basic information have the first priority to be conducted among ES studies. Once basic information is sufficiently accumulated, researchers can perform applied ES research with accuracy. Finally, results of ES studies conducted by five approaches allow decision makers to consider both natural system and society simultaneously, and hence the results can be utilized for sustainable development and conservation policy based on ecosystem-based management.
\end{abstract}

Keywords: Ecosystem Service, Social-ecological systems, Human well-being, Mapping, Valuation, Trade-off

\section{INTRODUCTION}

In South Korea, ecological conditions have deteriorated substantially due to rapid industrialization and urbanization since the 1960s (Ahn et al. 2010, Wackernagel et al. 2004). Destruction of ecosystems has negatively affected the provisioning of ecosystem goods and services (Seppelt et al. 2011). The conflict, however, between conservation and development policy still exist even among government ministries, and conventional development project have priority over conservation policy. This often results not only deterioration of ecosystem conditions but also threatening on human well-being.

To overcome this problem, policy makers should understand both society and ecosystem characteristics represented as Social-Ecological Systems (SESs) to find a balance between development and conservation. At this juncture, research on ecosystem services plays an important role by providing a preliminarily data for establishing Ecosystem-Based Management (EBM) policy, because the concept of ecosystem services contains integrity of ecosystems as well as human well-being; ecosystem service is defined as 'the benefits that human obtains from ecosystems'(Millennium Ecosystem Assessment 2005).

Most of researchers in South Korea still utilized unclear definition of ecosystem function and ecosystem service, and have not exactly grasped the concept of ecosystem service. For example, a few studies used terminology of

\section{Open Access http://dx.doi.org/10.5141/ecoenv.2013.001}

This is an Open Access article distributed under the terms of the Creative Commons Attribution Non-Commercial License (http://creativecommons. org/licenses/by-nc/3.0/) which permits unrestricted non-commercial use distribution, and reproduction in any medium, provided the original work is properly cited.
Received 06 February 2013, Accepted 28 February 2013

*Corresponding Author

E-mail: hj_kang@yonsei.ac.kr

Tel: +82-2-2123-5803 
ecosystem service equivalently with the economic value of ecosystem functions (Ahn et al. 2011). In addition, although ministry of environment of South Korea wants to carry out various ecosystem service researches until 2020, there is no manual for such studies and no project related to ecosystem service at national scale (Ministry of Environment 2012).

Thus, this article introduces the concept of ecosystem service and related terminologies: Social-Ecological Systems (SESs), ecosystem function, ecosystem service, trade-off, and human well-being. In addition, we reviewed and arranged the approaches for ecosystem service research then we suggest important subjects of service studies. The results of this article can help researchers to make a research planning of ecosystem service, and we show how policy makers can utilize the results for sustainable development and conservation policy based on the concept of ecosystem-based management.

\section{CONCEPT}

\section{Social-Ecological Systems}

To understand the concept of ecosystem service, we have firstly to consider a new framework of 'social-ecological systems'. Under such framework, then, ecosystem services can be defined and understood.

Human society is closely related to natural systems for which 'Social-Ecological Systems (SESs)' is one of the central concepts for better understanding of the interactions between human being and natural components (Liu et al. 2007). SES is defined as "A coherent system of biophysical and social factors that regularly interact in a resilient and sustained manner (Redman et al. 2004). It can be defined at several spatio-temporal scales in which several key resources (natural, socioeconomic and cultural) cycled or flow. An important point here is that such flow or cycle is regulated not only by a natural process but also by a combined influence of ecological and social systems. In that sense, SES emphasizes the integrated processes of human beings and nature and negate conventional dichotomy between a social system and an ecological system. For example, water chemistry of a river cannot be fully understood without consideration of economic activities of human in a watershed where the river is located.

Dynamics of SES has non-linear attributes such as thresholds, reciprocal feedback loops, time lags and resilience (Liu et al. 2007). Scientific knowledge emerged from interdisciplinary studies plays a key role in sustaining
SESs by providing baseline information. However, ecological studies and social sciences often fail to converge because both fields of studies have developed independently for a long time (Ostrom. 2009). As such, the complexity of SES has yet been to be fully understood even if much effort has been made to elucidate human-nature interactions (Liu et al. 2007, Scheffer et al. 2001).

Ostrom (2009) divided SES into four subsystems of resource system (e.g., a coastal fishery), resource units (octopus, crab), users (fishers) and governance systems (organizations and rules that govern fishing on the coast). Those subsystems are interrelated with relevant ecosystems (coastal wetland), socio-economic and political settings as well as interact each other. As all subsystems are interlinked so closely that degradation of a single subsystem can pose a serious threat to other subsystems (Rockstrom et al. 2009). This framework facilitates to set parameters that are needed to understand a single SES of a coastal fishery and fishers in a certain coastal wetland area (Ostrom 2009).

Representative studies employing SES concept include those conducted by 'Millennium Ecosystem Assessment' (2005) and 'The Economics of Ecosystem and Biodiversity' (2010) under framework of UNEP (Millennium Ecosystem Assessment 2005; Sukhdev et al. 2010). The Millennium Ecosystem Assessment dealt with interdisciplinary research between science and policy to connect nature and human. This approach provides possibility for the prediction and quantification of impacts of human activities and policy on ecosystems, their services, and human well-being (Carpenter et al. 2009). The Economics of Ecosystem and Biodiversity, in turn, estimated the global economic benefits from biodiversity as well as costs from the loss of biodiversity and ecosystems. Additionally, it provided expertise on actions to mitigate the loss of biodiversity and ecosystems by combining knowledge from science, economics and policy (Costanza et al. 2011).

\section{Ecosystem Service}

Understanding on ecosystem services should start with traditional concepts in ecology such as ecosystem functions and processes. Then, definitions, types and scopes of ecosystem services will be discussed.

\section{Ecosystem function and processes}

Ecosystem function is defined as "the capacity of natural processes and components to provide and services that satisfy human needs, directly or indirectly' (De Groot and Ecologiste 1992, de Groot et al. 2002). Ecosystem 


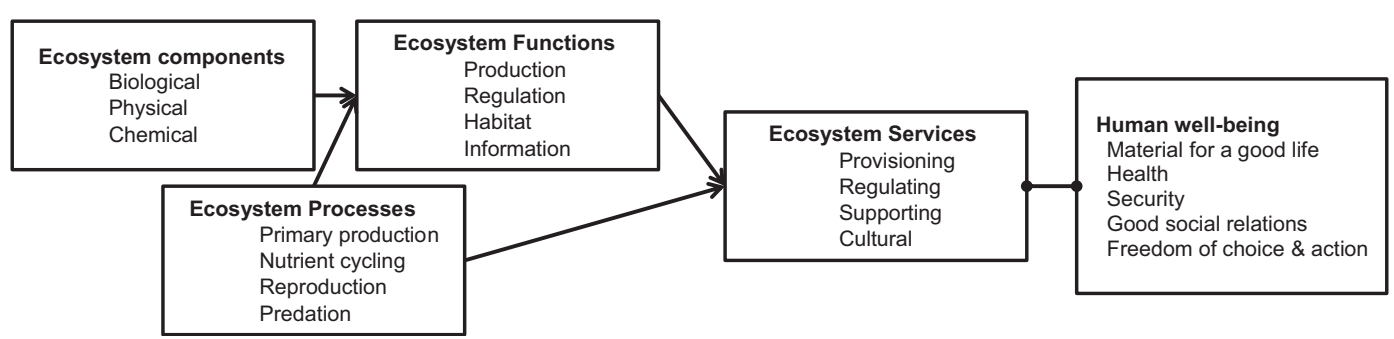

Fig. 1. Conceptual connections among ecosystem component, processes, functions, services and human well-being

functions appear as a result of ecosystems processes in a certain ecosystem. Here, ecosystem processes are an output of complex interactions among biotic and abiotic components of an ecosystem. de Groot et al. (2002) classified ecosystems functions as production functions (e.g., food and raw materials), regulatory functions (e.g., nutrient cycling, climate regulation), habitat functions(e.g., refugium function, nursery function) and information functions (e.g., aesthetic information, scientific and educational information). Ecosystem functions and processes vary spatially and temporally, which affects ecosystem services from them (Barbier 2012, Barbier et al. 2011, Koch et al. 2009). But, ecosystems functions and processes per se are not included in ecosystem services because they do not consider the realization of benefit to human society (Costanza et al. 1997, Costanza et al. 2011, de Groot et al. 2002)

\section{Definition of Ecosystem Service}

Ecosystem services are 'the direct and indirect contributions of ecosystems to human well-being' (Sukhdev et al. 2010). They are classified into four categories namely provisioning services (e.g., capture fisheries, genetic resource), regulating services (e.g., climate regulation, natural hazard regulation), supporting services (e.g., recreation and ecotourism) and cultural services (e.g., nutrient cycling, water cycling) (Millennium Ecosystem Assessment 2005). Ecosystem services are originated from ecosystem functions and processes, which makes contribution to human well-being directly or indirectly (Costanza et al. 1997, Costanza et al. 2011, Millennium Ecosystem Assessment 2005). This relationship can be summarized as Fig. 1.

\section{Scale and Trade-off}

From local to global scales, environmental changes including global climate change become greater in their intensity, which reduces resilience and integrity of ecosystems including coastal regions (Lenton et al. 2008,
Luisetti et al. 2011, Millennium Ecosystem Assessment 2005, Rockstrom et al. 2009). To cope with such changes, countries and many international organizations propose various political solutions. However, mismatch in scales between ecosystem functions/processes and influences of such policy often results in reduced ecosystem services (Carpenter et al. 2009). For example, provisioning services such as crop production and seafood supply has increased rapidly, but it has accompanied by reduction in regulating and cultural services along with biodiversity (Rodríguez et al. 2006, Sukhdev et al. 2010). If enough information had been available regarding trade-offs between different ecosystem services or between ecosystem services and human well-being, loss could have been reduced by compensating a loss in a certain service (e.g., recreation) by another service (e.g., disease regulation) through decision making among policy makers or related societies (Carpenter et al. 2009). As such, quantitative information about trade-offs between different ecosystem services or between ecosystem services and human well-being is of great importance (Costanza et al. 2011, Kareiva et al. 2007, Rodríguez et al. 2006).

\section{Human well-being}

Ecosystem services support human well-being by providing various ecosystem services to the human society. Here well-being is defined as 5-dimensional multivariate state composed of basic material for a good life, health, security, good social relations, and freedom of choice and action (Millennium Ecosystem Assessment 2005). Various studies on ecosystems services including Millennium Ecosystem Assessment (2005) attempted to conduct interdisciplinary research between ecological and social science, and constructed a framework to detect the capacity of maintain human well-being at various scales from local to global (Carpenter et al. 2009, Daw et al. 2011, Horwitz and Finlayson 2011, Millennium Ecosystem Assessment 2005, Perrings et al. 2010, Sukhdev et al. 2010). These studies have suggested that estimation 


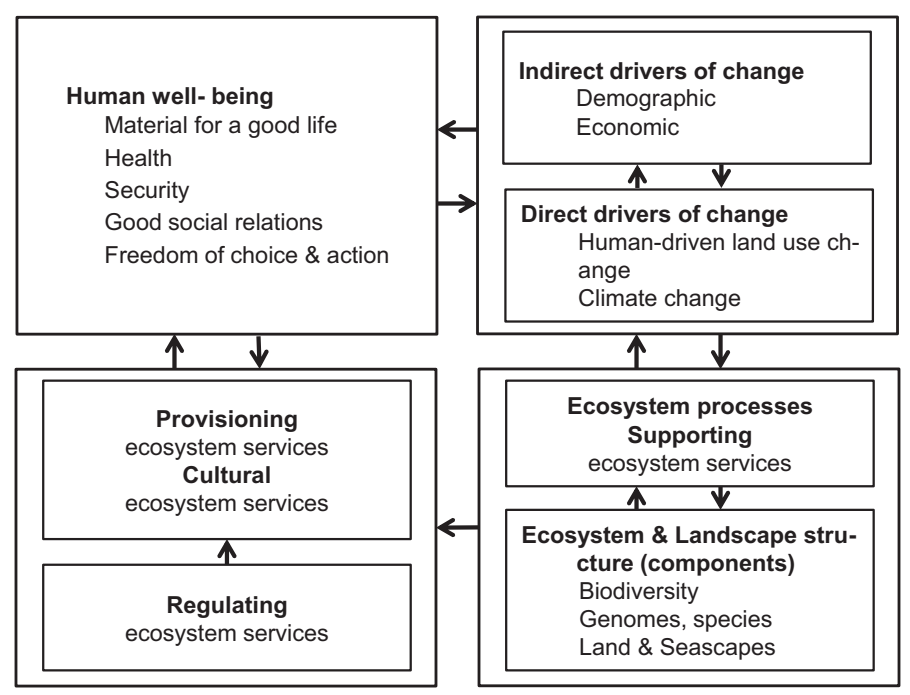

Fig. 2. Conceptual framework of interactions between ecosystem structure and process, ecosystem services, human well-being, indirect drivers and direct drivers (modified from Carpenter et al. (2009) and Millennium Ecosystem Assessment (2005))

and prediction of effects on ecosystem process and functions, ecosystem services and human well-being caused by policy making and human activities. Fig. 2 represents relationship and interactions between human well-being and ecological characteristics (ecosystem processes and services) in Social-Ecological Systems with a clear spatialtemporal range. This framework includes indirect drivers (which affects social well-being such as economic growth rate or social values but does not influence ecosystems directly), direct drivers (which directly modify ecosystems such as land use changes or volcanic eruption), ecosystem structure (component) and processes, ecosystem services, and human well-being (Finlayson et al. 2005, Millennium Ecosystem Assessment 2005).

\section{APPROACH}

In South Korea, one of the purposes of ecosystem service studies is to provide a preliminarily data for Ecosystem-Based Management (EBM) policy (Ministry of Environment 2012). At this time, the important goal of EBM is to offer various ecosystem services to humans over the long term, so the EBM approach helps to find the way how policy makers maintain balance between conservation and development (Lester et al. 2010; McLeod et al. 2009). That is, the results of ES researches are able to be utilized in the decision-making processes at national governments or local community scale. From this point of view, we summarized the major subjects of ecosystem service study as follows: 1) mapping the distribution of ecosystem services 2) estimating the value of ecosystem services 3) quantifying trade-off between services 4) understanding Social-Ecological Systems (SESs) (Lester et al., 2010, Seppelt et al. 2011). And to carry out researches with above subjects, field works which contain ecological characteristics and survey should precede before all (Fig. $3)$.

\section{Field Work}

Field work largely divides into finding ecological characteristics and performing survey and they provide basic information for ecosystem service studies. To figure out ecological characteristics of specific ecosystems, experimental research and modeling of nutrient cycle are required (Faulkner et al. 2008, MLTM 2012b). Then we can get the information about biophysical and biogeochemical factors. In addition, census data, geospatial data and information about socio-economic factors can be gotten by carrying out scientific and sociological survey. Also, survey based on preference-based approaches are often used for estimating willingness to pay of ecosystem functions or services (Champ and Boyle 2003, Freeman Iii 2003). At this time, the quantitative and qualitative data of field works determine significantly the accuracy of ecosystem service studies. Thus, national information sys- 


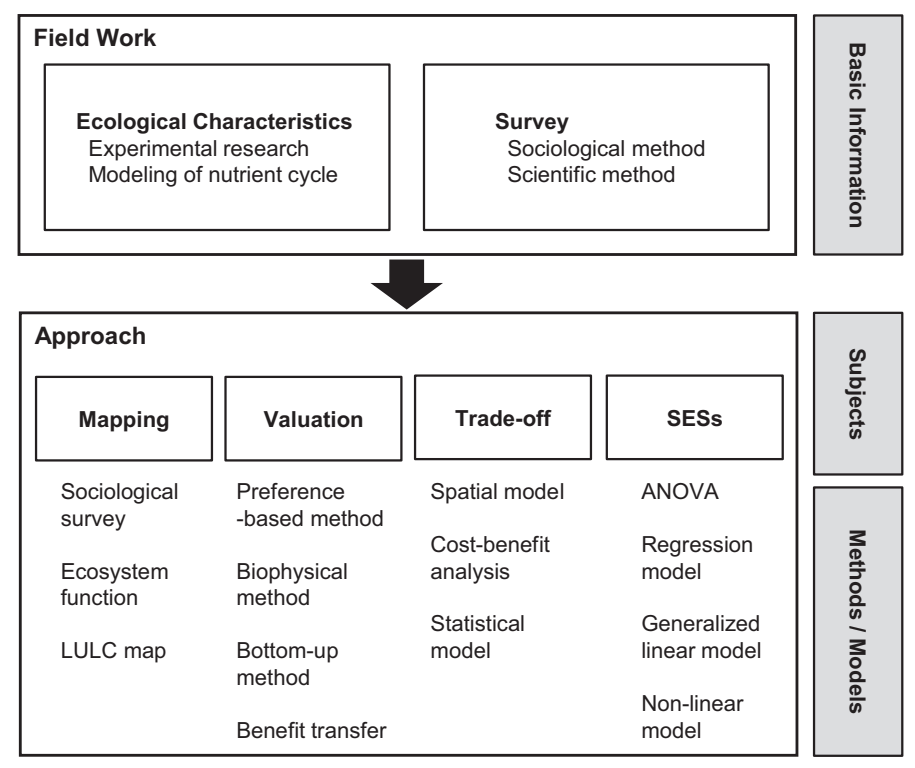

Fig. 3. Approaches for ecosystem service study

tems for the results of field works are required to ecosystem service research. In South Korea, these information systems are at an early stage, and government ministries of South Korea are providing various types of information systems as follow: Korean Statistical Information Service (Korea Statistics 2012a), National Spatial Information Clearinghouse (MLTM 2012c), Statistical Geographic Information Service (Korea Statistics 2012b), Coastal Management Information System (MLTM 2012a), Korean Tidalflat Information System (MLTM 2012b), Environment Geographic Information System (Minstry of Environment 2012), Environmental Valuation Information System (Korea Environment Institute 2012).

\section{Mapping ecosystem services}

The question of mapping ecosystem services is how ecosystem services are distributed in the study site, so mapping analysis helps decision makers to provide the sites where high density of ecosystem services is distributed. To solve this question, researchers use basically Geographic Information System (GIS) as disciplinary framework. More specifically, methods for mapping the distribution of ecosystem services are largely divided into three parts: using the results of sociological survey, ecological characteristics, and land use land cover (LULC) map. First, hotspots of ecosystem services are assessed by local residents or expert groups using mail survey or indepth interview (Alessa et al. 2008, Raymond et al. 2009).
Second, the information of ecological characteristics make it possible to map and quantify specific ecosystem service such as carbon storage in terrestrial ecosystems (Davies et al. 2011). Finally, by adding attributes of each LULC type, researchers can utilize LULC map not only for finding current state of ecosystem services but also for figuring out temporal change of ecosystem services according to future land use scenarios (Chung 2012, Polasky et al. 2011, Tallis et al. 2011).

\section{Estimation the value of ecosystem services}

The question of estimating the value of ecosystem services is how much the value of each ecosystem service or total economic value of ecosystem services is in the study area. To solve this question, economics is used as disciplinary framework. At this time, various methods for estimating each service have been constantly developed: biophysical approach, preference-based approach, bottom-up approach, and benefit transfer, and (Champ and Boyle 2003, Freeman 2003, Sukhdev et al. 2010). The most of provisioning services including seafood and crops are closely related to market value, so we can estimate these services using market analysis as direct-use value (Dahl et al. 2009). The value of flood damage mitigation or greenhouse gas regulation grouped by regulating services are classically estimated by avoided cost method and replacement cost methods, and bottom-up approaches recently estimate regulating services by integrating ecosys- 
tem function measurements, ecological modeling, and economic valuation (Chan and Ruckelshaus 2010, Jenkins et al. 2010, Montzka et al. 2011). In addition, although researchers have not estimated the value of many cultural services such as aesthetic and sense of place values, the worth of recreation and ecotourism have been assessed by preference-based approach: travel-cost method, hedonic pricing, contingent valuation method, and conjoint analysis (Chan and Ruckelshaus 2010). Moreover, studies for estimating services are often integrated with mapping analysis, then the results show both the value of ecosystem services and the spatial distribution and hotspots of services (Sherrouse et al. 2011).

\section{Trade-off between services}

It is important to identify and evaluate trade-offs between ecosystem services, because information on tradeoffs among services have not been fully understood yet (Luisetti et al. 2011, Millennium Ecosystem Assessment 2005). If information about trade-offs between services are well constructed, decision makers can establish optimum plan of management which balances the provision of various ecosystem services in a specific area (Carpenter et al. 2009). For this purpose, researchers are mainly utilizing three approaches as follows: spatial model with management scenarios, using the concept of cost-benefit analysis, and statistical model with non-monetary measures (Lester et al. 2010, Luisetti et al. 2011, Tallis et al. 2011). First, by using spatial model such as Integrated Valuation of Ecosystem Services and Trade-offs (InVEST), we can figure out how spatial distributions of ecosystem services change with different management options (Goldstein et al. 2012, Polasky et al. 2011, Tallis et al. 2011). Second, cost-benefit analysis is able to evaluate the tradeoffs represented as monetary unit between the two services or between management plans (Luisetti et al., 2011). At this time, ecosystem services are limited to having a market value for cost-benefit analysis. Finally, the correlations among services are assessed by statistical model with non-monetary measures, so trade-offs among many non-market services can be estimated instead of costbenefit analysis (Seppelt et al. 2011, Smith et al. 2011, Ziv et al. 2012).

\section{Understanding Social-Ecological Systems}

The concept of Social-Ecological Systems enable to involve human well-being and stakeholders in ecosystem service studies, so researchers can identify and quantify the relationships between human and natural systems by understanding SESs (Liu et al. 2007, Seppelt et al. 2011).
For this purpose, statistics and econometrics are used as disciplinary framework, and the most commonly used statistical models are in the following: ANOVA, regression model, time-series, generalized linear model, and nonlinear model (Smith et al. 2011). More specifically, the studies for understanding SESs treat generally three subjects, the first of which is that early studies of SESs found primary correlation between ecosystem functions and socioeconomic factors with non-linear model or regression analysis (Hope et al. 2003, Liu et al. 2007). From the results, researchers may determine ecological threshold in specific ecosystems with human interferences. Second, researchers evaluated how management programs or natural disasters affect ecological and socioeconomic status of local community such as income per capita with multiple regression models (Li et al. 2011; Liu et al. 2008, McSweeney and Coomes 2011). On the contrary, a few studies showed social and biophysical factors that influence on conservation or development by using regression model or generalized linear model (Chung 2012, Yackulic et al. 2011). Third, recent ES studies have attempted to conceptualize the relations of ecosystem services and human well-being (e.g. poverty alleviation and human health) (Daw et al. 2011, Horwitz and Finlayson 2011). To use the conceptualization, we can quantify and evaluate the relationships between ecosystem services and human well-being in the near future.

\section{DISCUSSION AND CONCLUSION}

This article aimed to provide decision makers with the concept of ecosystem service and related terminologies. In addition, we arranged important research subjects of ES as five approaches - field work, mapping, valuation, trade-off between services, and understanding SESs - of which results can be immediately used for establishing comprehensive management policy. Ecology is a disciplinary framework for ES studies, but the studies classified by five approaches require additional frameworks such as GIS, economics, statistics, econometrics and sociology. Thus, ES research should be conducted from an interdisciplinary perspective.

In South Korea, ES research is still at its early stage, so basic information obtained by field works and proper manuals for ES study have not been fully established. For this reason, national research projects need to focus on accumulating field works data (e.g. experimental research, modeling of nutrient cycle, census data at a local level, and high-resolution spatial data) for the long-term 
and building integrated information system in the years ahead. Also, researchers for ES studies should organize an interdisciplinary team which contains various fields of study like ecology, economics, statistics, and sociology. If basic information from field works and integrated information system are well constructed, we can easily carry out mapping and valuing ecosystem services. From the results of mapping and valuation, trade-offs between services can be evaluated, whereas the study of understanding SESs performs independently only using field works data.

As was stated above, the results of ES studies conducted by five approaches provide various information to the decision making process for sustainable development plan or comprehensive management program by considering both natural systems and local communities. In addition, decision makers are able to expect how several management options affect not only the quality of ecosystem services but local community, because ES studies contain socioeconomic information like income per capita as well as ecological information like biodiversity of a specific ecosystem. Therefore, it allows decision makers to establish sustainable development plan or suitable management program across study sites based on EBM.

\section{Acknowledgements}

This study was supported by NRF (20120008675), S/ ERC (20120009247) and Ecostar project (08-3-12).

\section{LITERATURE CITED}

Ahn HY, Park SY, Choi CU, Kim SY. 2010. Ecosystem service value assessment by change of land cover area in South korea, pp. 202-208.

Ahn SS, Bae DH, Lee CH. 2011. Construction of an environmental valuation database and analysis of valuation studies of Korea 3. Korea Environment Institute, Seoul, Korea.

Alessa L, Kliskey A, Brown G. 2008. Social-ecological hotspots mapping: A spatial approach for identifying coupled social-ecological space. Landscape and Urban Planning 85: 27-39.

Barbier EB. 2012. Progress and Challenges in Valuing Coastal and Marine Ecosystem Services. Review of Environmental Economics and Policy 6: 1-19.

Barbier EB, Hacker SD, Kennedy C, Koch EW, Stier AC, Silliman BR. 2011. The value of estuarine and coastal eco- system services. Ecological Monographs 81: 169-193.

Carpenter SR, Mooney HA, Agard J, Capistrano D, DeFries RS, Diaz S, Dietz T, Duraiappah, AK, Oteng-Yeboah A, Pereira HM, Perrings C, Reid WV, Sarukhan J, Scholes RJ, Whyte A. 2009. Science for managing ecosystem services: Beyond the Millennium Ecosystem Assessment. Proceedings of the National Academy of Sciences of the United States of America 106: 1305-1312.

Champ PA, Boyle KJ. 2003. A primer on nonmarket valuation. Springer, Dordrecht, The Netherlands.

Chan KM, Ruckelshaus M. 2010. Characterizing changes in marine ecosystem services. F1000 biology reports 2: 54 .

Chung MG. 2012. Mapping ecosystem services and statistical analysis for Ecosystem-Based Management of coastal areas, School of Civil and Environmental Engineering. Master. Yonsei University, Seoul, Korea.

Costanza R, dArge R, deGroot R, Farber S, Grasso M, Hannon B, Limburg K, Naeem S, Oneill RV, Paruelo J, Raskin RG, Sutton P, vandenBelt M. 1997. The value of the world's ecosystem services and natural capital. Nature 387: 253260.

Costanza R, Kubiszewski I, Ervin D, Bluffstone R, Boyd J, Brown D, Chang H, Dujon V, Granek E, Polasky S, Shandas V, Yeakley A. 2011. Valuing ecological systems and services. F1000 biology reports 3: 14 .

Dahl R, Ehler C, Douvere F. 2009. Marine Spatial Planning, A Step-by-Step Approach toward Ecosystem-based Management. IOC Manuals and Guides 53.

Davies ZG, Edmondson JL, Heinemeyer A, Leake JR, Gaston KJ. 2011. Mapping an urban ecosystem service: quantifying above-ground carbon storage at a city-wide scale. Journal of Applied Ecology 48: 1125-1134.

Daw T, Brown K, Rosendo S, Pomeroy R. 2011. Applying the ecosystem services concept to poverty alleviation: the need to disaggregate human well-being. Environmental Conservation 38: 370-379.

De Groot RS, Ecologiste PB. 1992. Functions of nature: evaluation of nature in environmental planning, management and decision making. Wolters-Noordhoff Groningen, Groningen, NL.

De Groot RS, Wilson MA, Boumans RMJ. 2002. A typology for the classification, description and valuation of ecosystem functions, goods and services. Ecological Economics 41: 393-408.

Faulkner S, Barrow W, Keeland B, Walls S, Moorman T, Twedt D, Uihlein III W. 2008. Assessment of Ecological Services Derived from US Department of Agriculture Conservation Programs in the Mississippi Alluvial Valley: Regional Estimates and Functional Condition Indicator Models. Interim Report. Washington, DC: USDA 
NRCS.

Finlayson M, Cruz RD, Davidson N, Alder J, Cork S, Groot RSd, Lévêque C, Milton GR, Peterson G, Pritchard D, Ratner BD, Reid WV, Revenga C, Rivera M, Schutyser F, Siebentritt M, Stuip M, Tharme, R., Butchard, S., DiemeAmting, E., Gitay, H., Raaymakers, S., Taylor, D., 2005. Millennium Ecosystem Assessment: Ecosystems and human well-being: wetlands and water synthesis. Island Press, Washington, DC.

Freeman AM. 2003. The measurement of environmental and resource values: theory and methods. Resources for the Future, Washington, DC.

Freeman Iii AM. 2003. The measurements of environmental and resource values: theory and methods. RFF press.

Goldstein JH, Caldarone G, Duarte TK, Ennaanay D, Hannahs N, Mendoza G, Polasky S, Wolny S, Daily GC. 2012. Integrating ecosystem-service tradeoffs into land-use decisions. Proceedings of the National Academy of Sciences 109: 7565-7570.

Hope D, Gries C, Zhu WX, Fagan WF, Redman CL, Grimm, NB, Nelson AL, Martin C, Kinzig A. 2003. Socioeconomics drive urban plant diversity. Proceedings of the National Academy of Sciences of the United States of America 100: 8788-8792.

Horwitz P, Finlayson CM. 2011. Wetlands as settings for human health: Incorporating ecosystem services and health impact assessment into water resource management. BioScience 61: 678-688.

Jenkins WA, Murray BC, Kramer RA, Faulkner SP. 2010. Valuing ecosystem services from wetlands restoration in the Mississippi Alluvial Valley. Ecological Economics 69: 1051-1061.

Kareiva P, Watts S, McDonald R, Boucher T. 2007. Domesticated nature: Shaping landscapes and ecosystems for human welfare. Science 316: 1866-1869.

Koch EW, Barbier EB, Silliman BR, Reed DJ, Perillo GME, Hacker SD, Granek EF, Primavera JH, Muthiga N, Polasky S. 2009. Non-linearity in ecosystem services: temporal and spatial variability in coastal protection. Frontiers in Ecology and the Environment 7: 29-37.

Korea Environment Institute (2012). Environmental Valuation Information System. http://evis.kei.re.kr. Accessed 22 January, 2013.

Korea Statistics (2012a). Korean Statistical Information Service. http://kosis.kr/. Accessed 22 January, 2013.

Korea Statistics (2012b). Statistical Geographic Information Service. http://sgis.kostat.go.kr/. Accessed 22 January, 2013.

Lenton TM, Held H, Kriegler E, Hall JW, Lucht W, Rahmstorf S, Schellnhuber HJ. 2008. Tipping elements in the
Earth's climate system. Proceedings of the National Academy of Sciences 105: 1786.

Lester SE, McLeod KL, Tallis H, Ruckelshaus M, Halpern BS, Levin PS, Chavez FP, Pomeroy C, McCay BJ, Costello C, Gaines SD, Mace AJ, Barth JA, Fluharty DL, Parrish JK. 2010. Science in support of ecosystem-based management for the US West Coast and beyond. Biological Conservation 143: 576-587.

Li J, Feldman MW, Li S, Daily GC. 2011. Rural household income and inequality under the Sloping Land Conversion Program in western China. Proceedings of the National Academy of Sciences 108: 7721.

Liu JG, Dietz T, Carpenter SR, Alberti M, Folke C, Moran E, Pell AN, Deadman P, Kratz T, Lubchenco J, Ostrom E, Ouyang Z, Provencher W, Redman CL, Schneider SH, Taylor WW. 2007. Complexity of coupled human and natural systems. Science 317: 1513-1516.

Liu JG, Li SX, Ouyang ZY, Tam C, Chen XD. 2008. Ecological and socioeconomic effects of China's policies for ecosystem services. Proceedings of the National Academy of Sciences of the United States of America 105: 94779482.

Luisetti T, Turner RK, Bateman IJ, Morse-Jones S, Adams C, Fonseca L. 2011. Coastal and marine ecosystem services valuation for policy and management: Managed realignment case studies in England. Ocean \&amp; Coastal Management 54: 212-224.

McLeod K, Leslie H, Aburto M, Alessa L, de los Angeles Carvajal M, Barr B, Barbier EB, Boesch DF, Boyd J, Crowder LB. 2009. Ecosystem-Based Management for the oceans. Island Press Washington DC.

McSweeney K, Coomes OT. 2011. Climate-related disaster opens a window of opportunity for rural poor in northeastern Honduras. Proceedings of the National Academy of Sciences of the United States of America 108: 5203-5208.

Millennium Ecosystem Assessment 2005. Ecosystems and human well-being. Island Press Washington DC.

Ministry of Environment 2012. A basic operational plan of the National Ecological Institute. Ministry of Environment, Gwacheon, Gyeonggi.

Minstry of Environment (2012). Environment Geographic Information System. http:// egis.me.go.kr/. Accessed 22 January, 2013.

MLTM (2012a). Coastal Management Information System. http://www.coast.kr. Accessed 22 January, 2013.

MLTM (2012b). Korean Tidalflat Information System. http:/ / www.tidalflat.go.kr. Accessed 22 January, 2013.

MLTM (2012c). National Spatial Information Clearinghouse. https://www.nsic.go.kr/. Accessed 22 January, 2013. 
Montzka SA, Dlugokencky EJ, Butler JH. 2011. Non-CO2 greenhouse gases and climate change. Nature 476: 4350.

Ostrom E. 2009. A General Framework for Analyzing Sustainability of Social-Ecological Systems. Science 325: 419422.

Perrings C, Naeem S, Ahrestani F, Bunker DE, Burkill P, Canziani G, Elmqvist T, Ferrati R, Fuhrman JA, Jaksic F, Kawabata Z, Kinzig A, Mace GM, Milano F, Mooney H, Prieur-Richard AH, Tschirhart J, Weisser W. 2010. Ecosystem Services for 2020. Science 330: 323-324.

Polasky S, Nelson E, Pennington D, Johnson KA. 2011. The impact of land-use change on ecosystem services, biodiversity and returns to landowners: A case study in the state of Minnesota. Environmental and Resource Economics 48: 219-242.

Raymond CM, Bryan BA, MacDonald DH, Cast A, Strathearn S, Grandgirard A, Kalivas T, 2009. Mapping community values for natural capital and ecosystem services. Ecological Economics 68: 1301-1315.

Redman CL, Grove JM, Kuby LH. 2004. Integrating social science into the long-term ecological research (LTER) network: social dimensions of ecological change and ecological dimensions of social change. Ecosystems 7: 161-171.

Rockstrom J, Steffen W, Noone K, Persson A, Chapin FS, Lambin EF, Lenton TM, Scheffer M, Folke C, Schellnhuber HJ, Nykvist B, de Wit CA, Hughes T, van der Leeuw S, Rodhe H, Sorlin S, Snyder PK, Costanza R, Svedin U, Falkenmark M, Karlberg L, Corell RW, Fabry VJ, Hansen J, Walker B, Liverman D, Richardson K, Crutzen P, Foley JA. 2009. A safe operating space for humanity. Nature 461: 472-475.

Rodríguez JP, Beard TD, Bennett EM, Cumming GS, Cork SJ, Agard J, Dobson AP, Peterson GD. 2006. Trade-offs across space, time, and ecosystem services. Ecology and Society 11: 28.

Scheffer M, Carpenter S, Foley JA, Folke C, Walker B. 2001. Catastrophic shifts in ecosystems. Nature 413: 591-596.
Seppelt R, Dormann CF, Eppink FV, Lautenbach S, Schmidt S. 2011. A quantitative review of ecosystem service studies: approaches, shortcomings and the road ahead. Journal of Applied Ecology 48: 630-636.

Sherrouse BC, Clement JM, Semmens DJ. 2011. A GIS application for assessing, mapping, and quantifying the social values of ecosystem services. Applied Geography 31: 748-760.

Smith RI, Dick JM, Scott EM. 2011. The role of statistics in the analysis of ecosystem services. Environmetrics 22: 608-617.

Sukhdev P, Wittmer H, Schröter-Schlaack C, Nesshöver C, Bishop J, Brink P, Gundimeda H, Kumar P, Simmons B. 2010. The economics of ecosystems and biodiversity: mainstreaming the economics of nature: a synthesis of the approach, conclusions and recommendations of TEEB. TEEB, Nagoya, Japan.

Tallis HT, Ricketts T, Guerry AD, Wood SA, Sharp R, Nelson E, Ennaanay D, Wolny S, Olwero N, Vigerstol K, Pennington D, Mendoza G, Aukema J, Foster J, Forrest J, Cameron D, Arkema K, Lonsdorf E, Kennedy C, Verutes G, Kim CK, Guannel G, Papenfus M, Toft J, Marsik M, Bernhardt J. 2011. InVEST 2.3.0 User's Guide: Integrated Valuation of Ecosystem Services and Tradeoffs. The Natural Capital Project, Stanford.

Wackernagel M, Monfreda C, Erb KH, Haberl H, Schulz NB. 2004. Ecological footprint time series of Austria, the Philippines, and South Korea for 1961-1999: Comparing the conventional approach to an 'actual land area' approach. Land Use Policy 21: 261-269.

Yackulic CB, Fagan M, Jain M, Jina A, Lim Y, Marlier M, Muscarella R, Adame P, DeFries R, Uriarte M. 2011. Biophysical and Socioeconomic Factors Associated with Forest Transitions at Multiple Spatial and Temporal Scales. Ecology and Society 16: 15.

Ziv G, Baran E, Nam S, Rodríguez-Iturbe I, Levin SA. 2012. Trading-off fish biodiversity, food security, and hydropower in the Mekong River Basin. Proceedings of the National Academy of Sciences 109: 5609-5614. 